\title{
Research Article: Knowledge of weedicides used in Kharif season by the farmers in Amravati district
}

\author{
Article Chronicle : \\ Received : \\ 21.05.2018; \\ Revised : \\ 07.06.2018; \\ Accepted : \\ 21.06.2018
}

\section{KeY Words:}

Knowledge,

Weedicides, Chemical

weed control,

Technical knowledge,

Weed

Author for correspondence :

A.N. Deshmukh

Department of

Extension Education,

Shri Shivaji Agriculture

College, Amravati (M.S.)

India

Email : abhaydeshmukh

40@ rediffmail.com

See end of the article for

authors' affiliations
SUMMARY : The present study was conducted with specific objectives to study the knowledge of weedicides used in Kharif season by the farmers in Amravati district. For the study two talukas viz., Chandur railway and Nandgaon khandeshwar were selected on the basis of large area under two crops selected for the study viz., cotton and soybean from Amravati district and four villages from each taluka were selected randomly. From each village ten respondents were selected. Ex-post-facto research design was used for the research study. Data were collected by personally interviewing the respondents with the help of pre-tested structured interview schedule in face to face situation. Collected data were tabulated. Correlation analysis for interpretation of the findings were calculated. Two hypotheses were set for the study and were tested for acceptance or rejection. Results obtained after analysis were summaries as below. In case of personal profile of the respondents revealed that majority 42.50 per cent of the respondents were from middle age, 32.50 per cent of the respondents were educated upto junior college, 32.50 per cent of the respondents had small land holding, 51.25 per cent of the respondents engaged in only agriculture, 35 per cent of the respondents had low annual income, 57.50 per cent were having medium social participation, 60 per cent were having medium source of information, 47.50 per cent were in medium extension contact, 67.50 per cent of the respondents had medium market orientation. In case of knowledge the majority 90 per cent of the respondents had knowledge about weedicide spraying in cotton, 86.25 per cent had knowledge about post emergence application of weedicide in standing crop, 16.25 per cent of the respondent had knowledge about pre-emergence application of weedicide in cotton. In soybean the majority 92.50 per cent of respondents had knowledge about weedicide spraying, 93.75 per cent had knowledge about post emergence application of weedicide in standing crop, 90 per cent of the respondents had knowledge about dose of weedicide, 17.50 per cent of the respondent had knowledge about pre-emergence application of weedicide in soybean. Characteristics namely education, land holding, occupation, annual income, social participation, extension contact, market orientation had significant relationship with knowledge of chemical weed control. Whereas, age and source of information did not show any significant relationship with knowledge and adoption of chemical weed control.

How to cite this article : Dhande, V.R., Deshmukh, A.N., Gawande, S.N. and Wakale, S.V. (2018). Knowledge of weedicides used in Kharif season by the farmers in Amravati district. Agric. Update, 13(3): 270-274; DOI : 10.15740/HAS/AU/13.3/270-274. Copyright@2018: Hind Agri-Horticultural Society. 